\title{
A Review on Source Plants of Dronpushpi - Leucas cephalotes (Roth) Spreng and Leucas aspera Spreng
}

\author{
Review article
}

\begin{tabular}{c}
\hline Sachin Chavan $^{\mathbf{1}^{*}}$, Nishteswar $\mathbf{K}^{\mathbf{2}}$ \\
1. M.D. Scholar, 2. Professor and Head, \\
Dept. of Dravyaguna, I.P.G.T \& R.A ,G.A.U, Jamnagar. \\
\hline
\end{tabular}

\begin{abstract}
Dronpushpi is a classical medicinal plant attributed with certain specific indications like Vishamjwara, Kamala. Two different plant species of Leucas are taken in use in the name of Dronpushpi. Among them Leucas cephalotes (Roth) Spreng has been accepted as an official equivalent to Dronpushpi by the Central Council for Research in Ayurveda in its official formulary. It has also been mentioned in Unani Materia Medica. Leucas aspera Spreng is the most widely used substitute of Dronapushpi and is also equally important ethnobotanically. Leucas cephalotes (Roth) Spreng and Leucas aspera Spreng grow as a weed on wastelands and roadsides all over India from October to February. The plants are used as insecticides and indicated in traditional medicine for coughs, cold, painful swellings, chronic skin eruptions and rheumatism. Experimentally both the species have shown good antioxidant, hepatoprotective and antimicrobial activities. They contain $\beta$-sitosterol, triterpenoids, oleanolic acid, ursolic acid, phenolic compounds, diterpenes, glucosides as major chemical constituents. The current review revealed that Leucas cephalotes and Leucas aspera have number of potentials in therapeutic field.
\end{abstract}

Key words: Dronapushpi, Leucas aspera, Leucas cephalotes, Hepatoprotective, Antioxidant.

\section{Introduction:-}

Dronapushpi is botanically identified by two species of genus Leucas i.e. Leucas cephalotes (Roth) Spreng and Leucas aspera Spreng, belonging to family Lamiaceae. Both grow as annual herbs throughout India, Bangladesh, Afghanistan, Philippines and some other Africo-asian countries, blooming between the months of October to February. There is no reference of Dronpushpi in vedic literature. Ayurvedic classics refer Dronpushpi by various names like

\footnotetext{
*Corresponding Author:

Sachin Chavan

M.D. scholar,

Dept. of Dravyaguna

I.P.G.T \&R.A,G.A.U., Jamnagar

E-mail: sachin4u101@gmail.com
}

Kutumbaka, Sugandhaka, Kurubaka. Chakrapani in his commentary on Charak Samhita states Kutumbaka as Dronpushpi and includes it in Shaka varga(edible leafy vegetables). Dalhana in his commentary on Shushrut Samhita mentions Dronpushpi as Sugandhaka and Kutumbaka. and includes it in Sursadi gana. According to available literature Vrundamadhava was the first to quote its therapeutic indication, in Kamala in the form of collyrium, by the name Dronpushpi. This quotation has been incorporated by Chakradatta in Kamala chikitsa. He also mentions its use in Krimidant Chikitsa. Shodhala prescribed the Nasya of Dronpushpi in Patalgat rogas and as Anjana in Kamala. Sharangdhara has indicated the use of Dronapushpi swarasa along with Marich choorna in Vishamjwara. The plant is used 
traditionally in fever, cold, rheumatism, psoriasis and chronic skin eruptions.(1) It has also been incorporated very frequently in number of Siddha and Unani preparations.(1)

\section{Materials \& Methods:-}

Ayurvedic classics, lexicons and other compilatory treatises are reviewed for documenting the information about Dronapushpi.

The published works on L cephalotes and L aspera from journals and web pages are consulted to review various reported pharmacological activities.

\section{Meaning of Synonyms :- (2)}

- Kumbhayoni:- Flowers look like a pot or wide mouthed opening.

- Droni:- looks like a vessel.

- Dronapushpi:- Flowers are cup or pot shaped.
- Chatrakutumbaka:- Flowers are arranged in a circle and are having shape of a pot.

- Koudinya:- Useful in insect bite.

- Deerghapatra:- Leaves are linear and sharp

- Kutumbika:- Flowers look like a pot.

- Chitrakshupa:-The plant is bright coloured.

- Supushpa:- Small, beautiful flowers in bunches.

- Chitrapatrika:- Leaves having various shapes.

- Kusumbhaka:- Flowers white in colour and are of cup shaped.

- Phalepushpa- Flowers and fruits are arranged together or the flowers will be on the fruit.

- Kshavapatri:- Smell of leaves causes sneezing.

Information about Dronpushpi available in various lexicons is tabulated here.

\begin{tabular}{|l|l|l|}
\hline Name of Nighantu & Varga & Pharmacological actions \\
\hline 1. Shodal Nighantu(3) & Karviryadi & $\begin{array}{l}\text { Kaphaghna, Kamlahar, Krimighna, } \\
\text { Shophajit, Pakshaghat- vinashini. }\end{array}$ \\
\hline 3.Madhava Dravyaguna(5) & Vushadi & $\begin{array}{l}\text { Kaphagna, Kamalahar, Shophahara, } \\
\text { Tamakshwasahara, Kasahara. }\end{array}$ \\
\hline 4.Bhavprakash Nighantu(6) & $\begin{array}{l}\text { Ghaphaghna, Aamhara, Kamlahara, } \\
\text { Shothahara, Krimihara }\end{array}$ \\
\hline 5. Raj Nighantu(7) & Parpatadi & $\begin{array}{l}\text { Krimihara, Prahmehahara, Jwarahara, } \\
\text { Pittakara }\end{array}$ \\
\hline 6. Raja Vallabha(8) & Nanaaushadi & Kapha, Kamala, Krimi, Shophajit \\
\hline 7. Shaligrama Nighantu (9) & Guduchyadi & Same as Bhavaprakasha \\
\hline 8. Nighantu Adarsha(10) & Tulasyadi & - \\
\hline 9. Madanpal Nighantu (11) & Abhayadi & Vaata-pittahara \\
\hline 10. Priya Nighantu(12) & Shatpushpadi & Vishaghna, Panduhara \\
\hline 11. Paryaymuktavalli & Tikta-shaka & - \\
\hline 12. Hridaya Dipaka \\
Nighantu
\end{tabular}




\begin{tabular}{|l|l|lr|}
\hline $\begin{array}{l}\text { 13. Sidhamantra Prakash } \\
\begin{array}{c}\text { 13.Dravyaguna } \\
\text { Vijnana(13) }\end{array}\end{array}$ & Kaphaghna & - & \\
\hline 14. Madhav dravyaguna & $\begin{array}{l}\text { Vividha- } \\
\text { Aushadhi }\end{array}$ & $\begin{array}{l}\text { Raktashodhaka, } \\
\text { Aartavajanaka, } \\
\text { Swedajanaka. }\end{array}$ & - \\
\hline 15 Dravyaguna vignan(14) & Tulasyadi & - & \\
\hline
\end{tabular}

Pharmacological properties of Dronapushpi

\begin{tabular}{|l|l|l|l|}
\hline Rasa & Guna & Virya & Vipaka \\
\hline $\begin{array}{l}\text { Katu, Lavana, } \\
\text { Madhura, Tikta }\end{array}$ & $\begin{array}{l}\text { Tikshna,Guru, } \\
\text { Ruksha }\end{array}$ & Ushna & Madhura, Katu \\
\hline
\end{tabular}

\section{Chemical constituents of Leucas aspera:- \\ Preliminary chemical examination}

of $L$. aspera revealed presence of triterpenoids in entire plant. Whole plant is reported to contain oleanolic acid, ursolic acid and 3-sitosterol. Aerial parts are reported to contain nicotine, sterols, $\alpha \& \beta$ sitosterol, reducing sugars( galactose), glucoside, diterpenens (leucasperosides A \& B, leucasperols A \& B, isopimarane glycosides (leucasperosides A, B \& C) together with other compounds like asperphenamate, maslinic acid,(-)isololiolide, linifoliside, nectandrin $\mathrm{B}$, mesodihydroguaiaretic acid, macelignan, acacetin, apigenin 7-O-[6'-O-(pcoumaroyl)-3-D-glucoside]' chrysoeriol, apigenin, erythro-2-(4-allyl-3,6dimethoxyphenoxy)-1-(4-hydroxy-3-

methoxyphenoxy)propan-1-ol,

myristargenol $\mathrm{B}$, and machilin $\mathrm{C}$, (-)chicanine, (7R,8R)-and(75,85)-licarin A. Among the 25 compounds identified from the leaf volatiles, u-farnesene $(26.4 \%)$, xthujene $(12.6 \%)$ and mentol $(11.3 \%)$ were the major constituents. The flower is reported to contain 10 compounds, among them amyl propionate $(15.2 \%)$ and isoamyl propionate $(14.4 \%)$ were dominant. Seed is reported to contain palmitic $\operatorname{acid}(6.25 \%)$, stearic $\operatorname{acid}(2.84 \%)$, oleic $\operatorname{acid}(42.07 \%)$, linoleic $\operatorname{acid}(48.11 \%)$ and linolenic acid. The unsaponifiable fraction contained 3-sitosterol and cetyl alcohol. Shoot contained novel phenolic compounds (4-(24-hydroxy-1-oxo-5-npropyltetracosanyl)-phenol), aliphatic ketols (28-hydroxypentatriacontan-2-one), long chain compounds (1hydroxytetratriacontan-4-one, 32methyltetratriacontane-8-ol), nonatriacontane, 5-acetoxytriacontane, $\beta$ sitosterol and dotriacontanol. Leucolactone(I), isolated from the root of $L$ aspera have been characterized as 3,3,16c-dihydroxyoleanan-28-1, 3olide.(15)

\section{Chemical constituents of Leucas cephalotes:-}

Plant:

$\beta$-sitosterol and its glycoside (Bahadur and Sen, 1969), new labdane, norlabdame and abietane type diterpenes named leucasdins A, B and C respectively, and two prostostane-type triterpenes named leucastrins A and B, oleanoic acid, 7-oxositosterol, 7-oxostigmasterol, $7 \alpha-$ hydrositesterol, $\quad 7 \alpha$ hydroxystigmasterol, stigmasterol, 5hydroxy-7,4'-dimethoxyflavone, pillion, gonzalitosin I, tricin, cosmosin, apigenin 7-O-beta-D-(6-O-p-coumaroyl) glucopyranoside, anisofolin A and luteolin 4'-O-beta-D-glucuronopyranoside (Miyaichi et al., 2006). 
Seed Oil- Laballenic acid (Octadeca-5, 6-dienoic acid), lauric acid, glutaric acid, tridecanoic acid, adipic acid ( Sinha at al, 1978)(16).

\section{Ethno-botanical uses of Leucas aspera:-}

Leucas aspera's water extract is used orally as stimulant, anthelmintic, laxative, and diaphoretic.(17). It is also used orally for the treatment of headache, asthma, and bronchitis.(18) Hot water extract of entire plant i.e Phanta is also used to treat inflammation, dyspepsia, and jaundice.(18) The whole plant extract is used orally to treat scabies, psoriasis, and snake bite. (19) The plant is externally used as an insect repellant in the form of Dhupan.(20) It is externally used to fumigate dwellings.(20) The flowers are roasted in ghee and given orally (5-10 g once a day) for treatment of cough and colds.(21) The flowers are crushed and inhaled in the opposite nostril for the relief of migraine.(22) The leaf juice is used for ear pain and for pus discharge from ear as a local application.(23) The leaf paste ground with chalk is applied to tooth cavity (periodontal) to prevent decay.(24) The decoction of leaves is used nasally as an anti-venum drug.(25) Infusion of leaves is applied externally to treat scabies.(26) Leaf paste along with turmeric is used to heal wounds and boils.(27) The decoction of whole plant of Leucas aspera are used orally for high fevers(28), for influenza(29), and for malarial fevers(30).

\section{Pharmacological Research studies of Leucas aspera:- \\ Acute and Sub-Acute Toxicity study}

A study was carried out to evaluate the acute and sub-acute toxicity of Leucas aspera in established animal model. It was found that EELA on oral administration produced no mortality or toxic effects on body up to a dose level of $2000 \mathrm{mg} / \mathrm{kg}$ body weight in acute toxicity study model. It did not produced any change in hematological parameters and induced any noteworthy damage to the vital organs. Hence, it can be concluded that at doses consumed in the traditional medicine, the ethanolic extract of Leucas aspera can be considered as relatively safe, as it did not caused either mortality nor it produced any severe toxicological effects on selected body organs, biochemical indices and hematological markers of rats during the acute and sub-acute periods of study.(31)

\section{Anti-asthamatic activity:-}

The anti-asthamatic effect of whole dried plant of Leucas aspera. This study showed that methanolic extract of the drug in the dose of $100 \mathrm{mg} / \mathrm{kg}$ showed a significant bronchodilatory, antihistaminic, anti-inflammatory, mast cell stabilization, and anti-cholinergic activity in histamine induced bronchospasm. It also showed convincing results in passive paw anaphylaxis, degranulation of mesenteric mast cell and histamine and acetylcholine induced contraction in guinea pig tracheal chain and ileum preparations models respectively. However, significant anti-allergic effect was not observed in milk induced eosinophilia. Thus, this study requires further evaluation to identify the active anti-histaminic component from methanolic extract of dried whole plant of Leucas aspera.(32)

\section{Anti-hyperglycemic Activity:-}

Evaluation of the antihyperglycemic effects of methanol extract of leaves and stem of Leucas aspera in oral glucose tolerance tests conducted with glucose-challenged Swiss albino mice was carried out. It was found that the leaf extract of L aspera was more potent in reducing serum glucose levels than stem extract.Hence the chemical constituents which are present in greater amount in leaves than stem should be found out and studied further for their anti-glycemic effect.(33) 
In another study of evaluating the effect of Leucas aspera alcoholic extract on blood glucose level in normoglycemic and diabetic rats, it was seen that the alcoholic extract of Leucas aspera showed hypoglycemic activity in chronically treated normoglycemic and diabetic rats. The blood glucose level did not show any changes on single administration of the plant extract on day 0 . There was an increase in levels at intervals of 30 and $60 \mathrm{~min}$. But on chronic administration the extract showed significant reduction in FBS levels, and was comparable to the reference drug metformin.(34)

\section{Antipyretic activity:-}

In the following experiment the extracts of Leucas aspera showed significant antipyretic activity. The researcher suggested further investigations to isolate active constituents responsible for this activity and to elucidate the exact mechanisms of action.(35)

\section{Antifungal activity:-}

Leucas aspera has both fungistatic and fungicidal properties. In an vitro study of chloroform and ether extracts of $L$. aspera it was revealed that $\mathrm{L}$ aspera possess strong antifungal activity against Trichophyton and Microsporum gypseum at minimum inhibitory concentration of $5 \mathrm{mg} / \mathrm{mL} . .(36)$

\section{Antimicrobial activity:-}

In a study $L$. aspera flowers were screened for its antibacterial activity in the form of its methanol extract, its fractions, the alkaloid residue and the expressed flower juice. All the groups showed good antimicrobial activity, with maximum activity in alkaloidal residue group.(37)

Essential oils from $L$. aspera were used for the trial. Bacteriostatic activity was found against Staphylococcus aureus, Vibrio cholerae, Salmonella typhi, Klebsiella aerogenes, Escherichia coli,
Proteus vulgaris, Pseudomonas pyocyanea and Dys. Flexneri.(38)

This experiment suggested that essential oil of L. aspera showed no activity against $\mathrm{E}$. coli, $\mathrm{P}$. aeruginosa, and C. albicans (MIC $\geq 1250 \mu \mathrm{g} / \mathrm{mL}$ ). L. aspera oil did exhibit good activity against $\mathrm{S}$. aureus $(\mathrm{MIC}=625 \mu \mathrm{g} / \mathrm{mL})$, B. cereus $(\mathrm{MIC}=313 \mu \mathrm{g} / \mathrm{mL})$, and $\mathrm{A}$. niger $(\mathrm{MIC}=$ $313 \mu \mathrm{g} / \mathrm{mL}$ ), most likely attributable to the sesquiterpenes present in the oil. Both (E)caryophyllene and $\alpha$-humulene have shown antibacterial activity against $B$. cereus and S. aureus.(39)

In another study, the Leucas aspera acetone leaf extract showed good antimicrobial activity against the gram positive microorganisms..(40)

A study was planned to screen the antimicrobial activity of different parts of L aspera. For this crude extracts of root, flower, leaf and stem were used as different group. The root extract showed the highest mean zone of inhibition ranging from $9.0-11.0 \mathrm{~mm}$ against tested microorganisms, at a concentration of 100 $\mathrm{mg} / \mathrm{mL}$.(41)

The above experiment give strong evidences to accept its classical claim of being mentioned as Krimihara. It must be noted that the potent anti-microbial activity is attributed to root and leaf. It can have good therapeutic potential against gram-positive organisms.

\section{Anti-inflammatory effect:-}

In a study anti-inflammatory activity was studied by formalin induced rat hind paw edema method with crude extract, alkaloid fraction and non-alkaloid fraction of L aspera and compared with Phenylbutazone. It was found that Phenylbutazone showed highest antiinflammatory activity followed by alkaloid fraction and crude extract. The nonalkaloid fraction did not show antiinflammatory activity irrespective of the time intervals.(42) 
The aqueous and alcoholic extracts of Leucas aspera were investigated for their action on experimental inflammation and on mast cell degranuatlion. Both the extracts exhibited significant antiinflammatory action of acute and chronic inflammation. The mast cell degranulation induced by proprancolol and Carbachol was effectively prevented by pretreatment with Leucas aspera extract.(43)

\section{Antioxidant activity:-}

A study was conducted to evaluate the anti-oxidant activity of different parts of Leucas aspera It was found that alcoholic extracts of the plant showed moderate to potent antioxidant activity, among which the root extract demonstrated the strongest antioxidant activity with the $\mathrm{IC}_{50}$ value of $6.552 \mu \mathrm{g} / \mathrm{mL}$. Methanolic extract of root possessed antioxidant activity near the range of vitamin E.(41)

In another study the ethanolic extract was subjected to acetic acid induced writhing inhibition, 1,1-diphenyl2- picryl hydrazyl (DPPH) free radical scavenging assay and brine shrimp lethality bioassay for screening of antinociceptive, antioxidant and cytotoxic activity, respectively. The researcher found that the ethanolic extract of $L$. aspera root produced significant inhibition in acetic acid induced writhing in mice at the doses of 250 and $500 \mathrm{mg} / \mathrm{kg}$. The extract showed a notrworthy free radical scavenging activity with an IC50 of 8 $\mu \mathrm{g} / \mathrm{ml}$ and a significant lethality to brine shrimp.(44)

\section{Anti-arthritic:-}

A was carried out to evaluate antiarthritic activity of L aspera . Its ethanolic extract exhibited significant antiinflammatory $(p<0.001)$ and antioxidant activity $(p<0.001)$. The drug was found safe upto a dose of $2000 \mathrm{mg} / \mathrm{kg}$ body weight. Histopathological studies also revealed cartilage regeneration in EELA2 treated arthritic rats. The researcher suggested that the anti-arthritic activity of EELA may be due to catechins (epicatechin, beta epicatechin), flavonoids (procyanidin), phytosterols (betasitosterol) apart from glycosides, phenolic compounds and tannins.(45)

\section{Antihelminthic activity:-}

The anthelminthic property of Leucas aspera was evaluated using Pherithema posthuma as an experimental model. Piperazine citrate was used as the standard reference.This investigation revealed that ethanol extract of Leucas aspera showed significant anthelminthic activity against Pheretima posthuma when compared aqueous extract. Ethanol extract also proved to be efficient than the standard drug. This investigation supported the ethnomedical claims of Leucas aspera as anthelminthic plant.(46)

\section{Anti-ulcer activity:-}

The alcoholic extract of Leucas aspera (ALA) was investigated for its antiulcer effect by two experimental models. A significant reduction in acid secretion and ulcer score was observed in rats after ALA treatment. The observer was of the opinion that the antiulcer effect of ALA may be due to a combination of anti-secretary effect and a protective effect on gastric mucosa.(47)

\section{Cytotoxic activity:-}

The cytotoxic properties of ethanolic extract of Leucas aspera (Family-Lamiaceae) were investigated in this study. The cytotoxic potential of the L. aspera ethanolic extract was assessed by brine shrimp lethality bioassay method. In this method LC50 value of L. aspera ethanolic extract was found $181.68 \mu \mathrm{g} / \mathrm{ml}$ with 95\% confidence limit where the lower and upper limits were 125.12 and $265.96 \mu \mathrm{g} / \mathrm{ml}$ respectively. This indicated that the extract had promising cytotoxic properties.(48) 


\section{Prostaglandin inhibitory and antioxidant activities:-}

Leucas aspera was tested for its prostaglandin (PG) inhibitory and antioxidant activities. The extracts showed both activities, that is, inhibition against PGE1 - and PGE2- induced contractions in guinea pig ileum at $3-4 \mathrm{~g} / \mathrm{mL}$ and a $1,1-$ diphenyl-2-picrylhydrazyl (DPPH) radical scavenging effect.(49)

In another study on the inhibitory action of Leucas aspera on prostaglandininduced contraction in guinea pig ileum, it provided four new diterpenes, leucasperones A (1) and B (2) and leucasperols A (3) and B (4), and three new isopimarane glycosides, leucasperosides A, B, and C (5-7), together with the known compounds asperphenamate, maslinic acid, (-)isololiolide, and linifolioside. Leucasperone A (1), leucasperosides A (5) and B (6), and linifolioside which showed inhibition of prostaglandin-induced contractions.(50)

\section{Hepato-protection:-}

To investigate the hepatoprotective action of methanolic extract of Leucas aspera on $\mathrm{CCl} 4$ induced liver damage in male Wistar rats a study was carried out. It was observed that the groups pretreated with L aspera and slymarin showed significantly decreased elevation of marker enzymes than the other groups. Hence it can be inferred that methanolic extract of L aspera showed hepatoprotective activity against CCL4 induced toxicity. It also suggested that the flavonoids present in $\mathrm{L}$ aspera is responsible for this activity.(51)

In another study of validating the hepatoprotective and antioxidant potential of methanolic extract of $\mathrm{L}$ aspera in CCL4 induced hepatotoxicity, convincing results were found supporting its hepatoprotective activity. Histological studies also supported the good recovery in MELA and standard pre-treated groups.
From this can be concluded that L aspera could be used for the development of phytomedicines against hepatic disorders. The hepatoprotective nature could be attributed to the presrnce of $\beta$ - sitosterol, alkaloids and flavonoids in it.(52)

\section{Larvicidal Activity:-}

The present study was carried to evaluate larvicidal activity of aqueous and chloroform leaf extract of Leucas aspera (willd.) against mosquito larvae Culex quinquefasciatus. Larvicidal effect on I, II, III and IV instar larvae of mosquito species Culex quinquefasciatus was investigated in a dose dependant manner for 48 hours. The concentration of the Leucas aspera extracts used was 1.0\%, $3.0 \%$ and $5.0 \%$. The Lethal concentration (LC50 and LC90) of both aqueous and chloroform extract were recorded. The results indicated that $100 \%$ mortality of I, II, III instar larvae of C.quinquefasciatus was observed at $5 \%$ concentration of Leucas aspera extract whereas, 1.0\% concentration of chloroform extract exhibited $100 \%$ mortality rate against all the four instar larvae of Culex quinquefasciatus. The results were statistically significant at $\mathrm{P}<0.05$ level. From the results it was inferred that the chloroform extract of Leucas aspera showed good larvicidal activity even at low concentrations compared to aqueous leaf extract of Leucas aspera.(53)

Another study concluded that the smoke of leaves of Vitex negundo and $L$. aspera are more toxic to the filarial vector mosquito, Culex quinquefasciatus than the synthetic mosquito mats, which contain $4 \%$ d-allethrin.(54)

In another study it was investigated for larvicidal and pupicidal activity against the first to fourth instar lavae and pupae of the laboratory-reared mosquitoes, $A$. stephensi. The plant extract showed larvicidal and pupicidal effects after $24 \mathrm{~h}$ of exposure. All larval instars and pupae had considerably moderate mortality; 
however, the highest larval mortality was found with ethanolic extract of whole plant of $L$. aspera against all the stages. The present study suggested that the ethanolic extracts of $L$. aspera and B. sphaericus can provide an excellent potential for controlling of malarial vector, $A$. stephensi.(55)

\section{Ethno-botanical uses of Leucas cephalotes:-}

The decoction of dried aerial parts of $\mathrm{L}$ cephalotes cures diarrhea and fever(56), (57). The water extract of entire plant (India) acts as a good appetizer.(58) The Poultice of its flowers and leaves are applied externally to treat headache.(59) The decoction of flower heads is used orally in Nepal to treat jaundice.(60) Its flower's decoction is used orally in India as an emmenagouge.(61) Hot water extract of dried flowers in India is used orally for cough and cold.(62),(63) The juice of unripe fruits (India) is applied externally to treat scabies.(64) The juice of leaves is used nasally as an antivenin.(65) The juice of leaves is used externally as an antivenin.(66) The dried leaves when administered internally act as a blood purifier.(67)

\section{Pharmacological study on Leucas cephalotes:-}

Antioxidant, analgesic and antiinflammatory activities:-

Evaluation for the Antioxidant, analgesic and anti-inflammatory activities of $L$ cephalotes was carried out. Methanolic extract from the whole plant of the Leucas cephalotes was screened for in vitro antioxidant (using the DPPH method), in vivo analgesic (using hot plate test in mice) and anti-inflammatory (using rat paw edema test) activities. The methanolic extract of Leucas cephalotes (MELC) scavenged the DPPH radicals in a dose-dependent manner. The IC50 value to scavenge DPPH radicals was found to be
$421.3 \mu \mathrm{g} / \mathrm{ml}$. A significant $\quad(\mathrm{p}<0.0005)$ analgesic activity was observed at $60 \mathrm{~min}$ with $200 \mathrm{mg} / \mathrm{kg}$, and $400 \mathrm{mg} / \mathrm{kg}$ exhibited maximum activity. The maximum antiinflammatory response was produced at 3 $\mathrm{hr}$ and $2 \mathrm{hr}$ with doses of 200 and 400 $\mathrm{mg} / \mathrm{kg}$, respectively. These results suggest that the methanolic extract from Leucas cephalotes exerts significant analgesic and anti-inflammatory effects, which were comparable with standard drugs.(68)

\section{Anti-Inflammatory activity:-}

Another study evaluated the antiinflammatory activity of different fractions and extracts of $\mathrm{L}$ cephalotes in dosedependent manner. The results showed that alkaloidal fractions of the leaves causes significant reduction in inflammation i.e $80 \quad \% \quad(100 \quad \mathrm{mg} / \mathrm{kg})$ followed by crude methanol extract i.e 61 $\%(100 \mathrm{mg} / \mathrm{kg})$, aqueous extract i.e $58 \%$ $(100 \mathrm{mg} / \mathrm{kg})$ compared to standard antiinflammatory drug aspirin i.e 68.62\% (25 $\mathrm{mg} / \mathrm{kg}$ ). This study provided evidence that the alkaloidal fraction and methanol extract of Leucas cephalotes acts as potent anti-inflammatory agent in rats in acute inflammation model.(69)

\section{Anti-bacterial:-}

The anti-bacterial activity of $\mathrm{L}$ cephalotes was evaluated. It showed that organic leaf extracts from methanol, hexane, ethylacetate and dichloromethane showed prominent antibacterial activity. The methanol and hexane extracts were found more potent against pathogenic strains of S.aureus, E.coli and Ps. Aeruginosa as compared to dichlomethane and ethylautate.(70)

\section{Anthelmintic activity:-}

In a study preliminary phytochemical screening of alcoholic extract was done which revealed the presence of anthraquinone glycosides, phenolic compounds and steroids. The aqueous extract showed presence of 
glycosides and phenolic compounds. The alcoholic extract of leaves of Leucas cephalotes demonstrated paralysis as well as death of worms in lesser time as compared to Piperazine citrate especially at higher concentration of $100 \mathrm{mg} / \mathrm{ml}$. Water extract also showed significant activity. It is assumed that phenolic content in the extracts of Leucas cephalotes is responsible for its antihelminthic effects.(71)

\section{Hepatoprotective effect:-}

1. This study investigated Leucas cephalotes for its anti-oxidant and hepatoprotective activity against CCL4 induced hepatitis. It concluded that the plant of Leucas cephalotes produced a variety of antioxidants against molecular damage from reactive oxygen species [ROS], produced by macrophages. The researcher is of the opinion that hepato-protective and antioxidant activity of Leucas cephalotes might be due to the presence of flavonoids in the methanolic extract.(72)

2. According to another study on $\mathrm{L}$ cephalotes, it possessed significant degree of hepato-protective effect against carbon tetrachloride induced hepatotoxicity. The drug probably produced effect by inhibition of oxidative stress, because it is proposed that carbon tetrachloride causes hepatic damage via oxidative degeneration.(73)

\section{Diabetes mellitus:-}

The study was aimed at evaluating the hypoglycaemic effect of ethanol extract of leaves of Leucas cephalotes. EELA was administered in increasing dose of 150,300 and $450 \mathrm{mg} / \mathrm{kg}$ of bw to diabetes induced (IDDM and NIDDM) rats and carbohydrate, lipid, antioxidant, urea and creatinine profiles were assessed. All the three doses of extract decreased plasma glucose and lipid profiles and improved the antioxidant status of both types of diabetic rats. The extract administration improved hepatic glycogen content and hexokinase activity, decreased glucose-6phosphatase activity, blood urea, creatinine contents and decreased lipid peroxidation in diabetic rats. The dose of $450 \mathrm{mg} \mathrm{kg}(-1) \mathrm{bw}$ dose was found to be more potent in its effects as compared to glibenclamide and metformin. Hence it can be said that $\mathrm{L}$ cephalotes produces a pronounced effect on carbohydrate and fat metabolism.(74)

\section{Carbonic Anhydrase I and II Inhibition:-}

The methanolic extract of Leucas cephalotes was tested for human carbonic anhydrase (HCA) I and II inhibition study. The study concluded that Leucas cephalotes is a weak inhibitor of carbonic anhydrase.(75)

\section{Discussion:-}

Dronapushpi is a classical ayurvedic herb indicated in various ayurvedic works which were documented during $1000 \mathrm{BC}$ to $1800 \mathrm{AD}$. The herb is indicated in conditions namely Kamala (Jaundice), Jwara (Fever), Krimi (worm infestation), Shopha (painful inflammatory conditions), Kasa (cough), Tamakashwasa (Bronchial asthama), Pandu (Anaemia) and Prameha (Urinary disorders). Dronapushpi is attributed with Vatahara, Kaphaghna, Vishaghna and Swedala activities.

Botanical source includes two varieties of Leucas genus i.e L cephalotes and L aspera. While majority of floras compiled during the 20th century suggested L aspera is the source plant of Dronapushpi, the official formulary of Ayush quoted Leucas cephalotes as the classical Dronapushpi. Various compendia indicate internal administeration of Dronapushpi in Vishamajwara (fever including malaria) and its corryllium for 
the management of Kamala (jaundice) and Patalgata rogas (eye disorders like cataract). A scientific validation has already documented with regard to its role in ccl4 induced Hepatitis.

Ethomedicinal uses of L cephalotes include the usage of entire plant in the treatment of diarrhoea and fever. Flowers are employed as emmenagouge and prescribed for flu. Fruits are externally applied for scabies and leaves for snake bites. L aspera leaf is administered internally in skin diseases like scabies and psoriasis, snake bite poison, bronchial asthma, headache and cough. Roasted flowers are administered to treat cold and cough. The paste of leaves is applied on wound along with turmeric. Leaf paste is also ground with chalk and filled in tooth cavity to prevent its decay.

The information of ethno-medicine clearly indicates that the two species which are considered as the botanical sources of Dronapushpi are applied in various conditions which are all referred in Ayurvedic texts. This part of information is a good source to explore the potentialities of these plants scientifically which may contribute new herbal leads in medicine.

\section{Conclusion:-}

Leucas cephalotes and Leucas aspera have been evaluated extensively for different pharmacological activities like anti-bacterial, antipyretic, hepatoprotective, analgesic activities and studies reported significant effect. Its ethno-botanical claims also suggest its use in fever, jaundice, rheumatism and skin disorders.

\section{References:-}

1. Kirtikar, K. R., and Basu, B. D. 1990. "Indian medicinal plants" (Ed) Bidtter, E. caius.J. F., and Mhaskar K. S. 2019.Periodical Expert's Book Company.
2. J.L.N. Shastry, Ayurvedokta Oushadha Niruktamala, Varanasi, Chaukhambha Orientalia,2001, p-59.

3. Shodhala, Shodhala Nighantu, edited by Sharma P.V, I edition, Baroda, Oriental institute, 1978, p-93,128.

4. Kaiyadeva, Kaiyadeva Nighantu, edited by Sharma P.V, Guruprasad Sharma, I edition, Varanasi, Chowkhamba Orientalia, 1979, p-123.

5. Madhav,

Madhavdravyaguna(Paryayratnamala), edited by Sharma P.V, I edition, Varanasi, Chowkhamba Vidhyabhavan, 1973, p-7

6. Bhavmishra, Bhavprakasha Nighantu, commentry by Chunekar K.C edited by Pandey G S Varanasi, Chowkhamba Bharti Academy, 2002, p-263.

7. Narhari, Raj Nighantu, Dravyaguna Prakashika, Indradev Tripathi, III edition, Varanasi, Chowkhamba Krishnadas Academy,2003, p-132.

8. Rajavallabh, Rajvallabh Nighantu, redacted by Narayan Das, Shaligram Vaishya, Dravyachandrika, Varanasi, kalyan, Lakshmivenkateshwara mudranalaya, 1952, p-187.

9. Shaligram Vaishya, Shaligram Nighantu, Mumbai, Khemraj, Shrikrishnadas Prakashan, 1998, p350.

10. Vaidya Bapalal G, Adharsha Nighantu, Vol-II, II edition, Varanasi, Chowkambha Bharti Academy.1999, p-279.

11. Madanpala, Madanpala Nighantu, Ramprasad, Tatvaprakashika Tika, Bombay, Khemraj, Shrikrishnadas Prakashan, 2004, p-52.

12. P.V. Sharma, Priya Nighantu, Varanasi, Chowkhamba Surbharti Prakashana, I edition, 2004, p-111.

13. Yadavji Trikamji, Dravyaguna vidyanam part-2,Sharma Ayurved mandir, 4th edition, pg-305-306.

14. P.V. Sharma, Dravyaguna Vignan, Varanasi, Chowkhamba Bharti Academy, vol 2, 2011, p-709-711. 
15. M.S Prajapati, J.B. Patel, K. Modi and M.B Shah on Leucas aspera: A review, Pharmacognsy Review vol 4(7), Janjun 2010, p-85-87.

16. Database on medicinal plants used in Ayurveda \& Siddha, CCRAS,Delhi, vol 8, p-74.

17. Balunas MJ, Kinghorn AD. Drug discovery from medicinal plants. Life Sci 2005;78:431-41.-1

18. Reddy MK, Viswanathan S, Thirugnanasambantham $\mathrm{P}$, Kamesawaran T. Analgesic activity of Leucas aspera. Fitoterapia 1993;64:151-4

19. Pushpangadan P, Atal CK. Ethnomedico-botanical investigations in Kerala I. Some primitive tribals of western ghats and their herbal medicine. J Ethnopharmacol 1984; 11:59-77

20. Girach RD, Aminuddin, Siddioui PA, Khan SA. Traditional plant remedies among the Kondh of district dhenkanal (Orissa). Int J Pharm 1994;32:274-83

21. Pushpangadan P, Atal CK. Ethnomedico-botanical investigations in Kerala I. Some primitive tribals of western ghats and their herbal medicine. J Ethnopharmacol 1984;11:59-77

22. Pushpangadan P, Atal CK. Ethnomedico-botanical investigations in Kerala I. Some primitive tribals of western ghats and their herbal medicine. J Ethnopharmacol 1984;11:59-77

23. Bhandary MJ, Chandrasekhar KR, Kaveriappa KM. Medical ethno botany of the siddis of Uttara Kannada district, Karnataka, India. J Ethnopharmacol 1995;47:149-58.

24. Bhandary MJ, Chandrasekhar KR, Kaveriappa KM. Medical ethno botany of the siddis of Uttara Kannada district, Karnataka, India. J Ethnopharmacol 1995;47:149-58.

25. ${ }^{1}$ Bhandary MJ, Chandrasekhar KR, Kaveriappa KM. Medical ethno botany of the siddis of Uttara Kannada district, Karnataka, India. J Ethnopharmacol 1995;47:149-58.

26. Selvanayahgam ZE, Gnanevendhan SG, Balakrishna K, Rao RB. Antisnake venom botanicals from ethno medicine. J Herbs Spices Med Plants 1994;2:45-100

27. Khaleque A, Huq ME, Huq MS, Mansoor MH. Chemical investigations on leucas aspera. I. Isolation of compound a, beta-sitosterol and alphasitosterol from the aerial parts. Sci Res (DACCA, PAK) 1970;7:125

28. Kapur SK, Sarin YK. Medico-botanic survey of medicinal and aromatic plants of katra valley (J. \& K.STATE) India. Indian Drugs 1984;22:4-10.

29. John D. One hundred useful raw drugs of the kani tribes of Trivandrum Forest Division, Kerala, India. Int $\mathrm{J}$ Crude Drug Res 1984;22:17-39

30. Pushpangadan P, Atal CK. Ethnomedico-botanical investigations in Kerala I. Some primitive tribals of western ghats and their herbal medicine. J Ethnopharmacol 1984;11:59-77.

31. K.G.Kripa, D.Chamundeeswari, J.Thanka, Acute And Sub-Acute Toxicity Evaluation Of Ethanolic Extract Of Leucas aspera (Lamiaceae) In Experimental Rats, International Journal of Drug Development \& Research| July-September 2011 | Vol. 3 | Issue 3.

32. KK Limbasiya, VR Modi, PR Tirgar, TR Desai, PN Bhalodia on evaluation of antiasthmatic activity of dried whole plant extract of $\mathrm{L}$ eucas aspera using various experimental animal models, International Journal of Phytopharmacology,

33. Abdul Mannan, Hirak Das, Mohibur Rahman, Jerin Jesmin, Aziza Siddika, Mahabuba Rahman, Shahnaz Rahman, Majeedul H. Chowdhury, Mohammed Rahmatullah: Antihyperglycemic Activity Evaluation of Leucas Aspera 
(Willd.) Link Leaf and Stem and Lannea Coromandelica (Houtt.) Merr. Bark Extract in Mice, Advances in Natural \& Applied Sciences;SepDec2010, Vol. 4 Issue 3, p385.

34. Shalini Adiga*, SagarV, Ravindrasingh.R, Vasantha. Evaluation of the effect of leucas aspera alcoholic extract on blood glucose level in normoglycemic and diabetic rats. 2011

35. Gupta N, Subhramanyam EVS, Jha S, Bhatia V, Narang E on A comparative antipyretic activity of the crude extracts of the plant Leucas aspera and Glycosmis pentaphylla, J. Chem. Pharm. Res., 2011, 3(1):320-323.

36. Thakur DK, Misra SK, Choudhuri PC Invitro trials of plant extracts and chemicals for their antifungal activity. Indidn J animal health 1987.

37. Mangathayaru K, Lakshmikant J, Shyam Sundar N, Swapna R, Grace XF, Vasantha J. Antimicrobial activity of leucas aspera flowers. Fitoterapia2005

38. Rao B, Narasimha GV. Antimicrobial actions of some essential oils. IV. Effect of organic compounds. Riechstoffe, Aromen, Koerperpflegemittel 1971

39. Schmidt JM, Noletto JA, Vogler B, Setzer WN, Abaco Bush medicine; chemical composition of essential oil of four aromatic medicinal plants from Abaco Island, Bahamas, J Herb Spices Medicinal plants, 2006,12;43-65

40. G. Manimekalai, S. Selvakumar, V. Gopikrishnan, M. Radhakrishnan and R Balagurunathan, Antibacterial Effect Of Medicinal Plants Leucas Aspera Linn And Ocimum Basilicum Linn, IJAPR / June 2011/ Vol. 2 / Issue. 6 / $276-280$.

41. Antioxidant and antibacterial activity of different parts of Leucas aspera Chew Ai Lan; Jessica Jeyanthi James Antony; Sasidharan Sreenivasan; Asian Pacific Journal of Tropical Biomedicine Volume: 2 Issue: 3
Pages:

$176-180$

DOI:

http://dx.doi.org/10.1016/S2221-

1691(12)60037-

9 Published:MAR2012.

42. ${ }^{1}$ Saundane AR, Hidayat Ull KM, Satyanarayan ND. Antiinflmmatory activity and analgesic activity of various extracts of Leucas aspera Spreng. Ind J Pharm Sci 2000;62:144 6.

43. Effect of leucas aspera on experimental inflammation and mast cell degranulation.

Reddy M K; Viswanathan S; Sambantham P T; et al.; Ancient science of life Volume: 5 Issue: 3 Pages: 168-71 Published:1986-Jan

44. Rahman MS, Sadhu SK, Hasan CM. Preliminary antinociceptive, antioxidant and cytotoxic activities of leucas aspera root. Fitoterapia 2007.

45. Kripa K. G.; Chamundeeswari D.; Thanka J.; et al , Modulation of inflammatory markers by the ethanolic extract of Leucas aspera in adjuvant arthritis.; Journal Of Ethnopharmacology Volume: 134 Issue: $\quad 3$ Pages: http://dx.doi.org/1024-1027 DOI: http://dx.doi.org/10.1016/j.jep.2011.01 .010 .

46. Swati Agarwal; Simi Jacob; Nikkita Chettri; et al, Evaluation of in vitro anthelminthic activity of Leucas aspera extracts..; Pharmacognosy Journal Volume: 3 Issue: 24 Pages: 77-80 DOI: http://dx.doi.org/10.5530/pj.2011.24.1 5 Published: 2011.

47. M. Kannappa Reddy, S. Viswanathan, P. Thiugnanasambhantham, and Lalitha Kameshwaran, Anti-Ulcer Activity Of Leucas Aspera Spreng,. Ancient Science of Life, Vol No. XII Nos. 1 \& 2, July-October 1992, Pages 257-260

48. Nipa Chowdhury, Talha Bin Emran, Dibyajyoti Saha, Md. Atiar Rahman and S.M. Zahid Hosen on Cytotoxic 
Potential of the Ethanolic Extract of Leucas aspera, Bulletin of Pharmaceutical Research 2012;2(2):87-90.

49. Sadhu SK, okuyama E, Fujimoto $H$, Ishibashi, M. Separation of leucas aspera, a medicinal plant of Bangladesh guided by prostaglandin inhibitory and antioxidant activities Chem Pharm Bull (Tokyo). 2003 May;51(5):595-8.

50. Sadhu Samir Kumar; Okuyama Emi; Fujimoto Haruhiro; et a, Diterpenes from Leucas aspera inhibiting prostaglandin-induced contractions 1.; JOURNAL OF NATURAL PRODUCTS Volume: 69 Issue: 7 Pages: $988-994$ DOI: http://dx.doi.org/10.1021/np058118m Published: JUL 282006

51. Mangathayaru K.; Grace X. Fatima; Bhavani M.; et al ,Effect of Leucas aspera on hepatotoxicity in rats.; Indian Journal of Pharmacology Volume:37 Issue:5 Pages:329330 Published:OCT2005.

52. B. Latha and M.S. Latha; Antioxidant and curative effect of Leucas aspera methanolic extract against carbontetra chloride induced acute liver injury in rats; International Journal of Pharmacy and Pharmaceutical Sciences; Vol 5, Issue 1, 2013.

53. Ramanibai R.; Madhavarani A.; Boomilingam M, Larvicidal efficacy of Leucas aspera (willd) extracts against the mosquito larvae of Culex quinquefasciatus..; Journal of Pharmacy Research Volume: 4 Issue: 12 Pages: 4424-4425 Published: 2011.

54. Selvaraj R, Revathy C, Charles A, Manoharan. Toxicity evaluation of herbal smoke and synthetic mosquito mat on culex quinquefasciatus. Geobias 1994

55. Kovendan Kalimuthu; Murugan Kadarkarai; Vincent Savariar; et al; Studies on larvicidal and pupicidal activity of Leucas aspera Willd. (Lamiaceae) and bacterial insecticide, Bacillus sphaericus, against malarial vector,Anophelesstephensi

Liston.(Diptera:Culicidae).; parasitology research Volume: 110 Issue: 1 Pages: 195-203 DOI: http://dx.doi.org/10.1007/s00436-0112469-2 Published: JAN 2012.

56. Pushpangadan P, Atal CK; Ethnomedico-botanical investigations in Kerala I. Some primitive tribals of western ghats and their herbal medicine. J Ethnopharmacol 1984;11:59-77.

57. Johns T, Faubert GM, Kokwaro JO, Mahunnah RL, Kimanani EK. Antigiardial activity of gastrointestinal remedies of the luo of east Africa. J Ethnopharmacol 1995;46:17-23.

58. Johns T, Kokwaro JO, Kimanani EK. Herbal remedies of the luo of siaya district, Kenya: Establishing quantitative criteria for consensus. Econ Bot 1990;44:369-81.

59. Saha JC, Savini EC, Kasinathan S. Ecbolic properties of Indian medicinal plants. Part 1. Indian J Med Res 1961;49:130-51.

60. Bhattarai NK. Traditional herbal medicines used to treat wounds and injuries in Nepal. Trop Doct 1997;27 (S-1):43-7

61. Selvanayahgam ZE, Gnanevendhan SG, Balakrishna K, Rao RB. Antisnake venom botanicals from ethno medicine. J Herbs Spices Med Plants 1994;2:45-100.

62. Sahu TR. Less known uses of weeds as medicinal plants. Anc Sci Life 1984;3:245-9.

[PUBMED]

63. Whistler WA. Traditional and herbal medicine in the Cook Islands. $\mathrm{J}$ Ethnopharmacol 1985;13:239-80. [PUBMED].

64. Holdsworth DK. Traditional medicinal plants of Rarotonga, Cook Islands. Part II. Int J Pharmacog 1991;29:71-9. 
65. Reddy MB, Reddy KR, Reddy MN. A survey of plant crude drugs of anantapur district, Andhra Pradesh, India. Int $\mathrm{J}$ Crude Drug Res 1989;27:145-55

66. Samuelsson G, Farah MH, Claeson P, Hagos M, Thulin M, Hedberg O. Inventory of plants used in traditional medicine in Somalia. II. Plants of the families' combretaceae to labiatae. J Ethnopharmacol 1992;37:47-70.

67. Tiwari KC, Majumder R, Bhattacharjee S. Folklore medicines from Assam and Arunachal Pradesh (District Tirap). Int J Crude Drug Res 1979; 17:61-7

68. Bhukya Baburao, Anreddy Rama Narsimha Reddy, Gangarapu Kiran, Yellu Narsimha Reddy, Gottumukkala Krishna Mohan on Antioxidant, analgesic and anti-inflammatory activities of Leucas cephalotes (Roxb.ex Roth) Spreng.,Brazilian Journal of Pharmaceutical Sciences vol. 46, n. 3, jul./set., 2010.

69. Mathur Abhishek , Gupta Vinay , Verma Satish K. , Singh Santosh K. , Prakash Archana, Prasad GBKS, Dua VK, International journal on current Pharmaceutical review and research, Vol I, issue 3, February 2011-April 2011.

70. Madhukiran B.L., Vijaya Lakshmi K., and Uma Maheswari Devi $\mathrm{P}$ on Antibacterial properties of Leucas cephalotes (roth) spreng. Leaf, Ancient science of life , Vol: XXI (4) April / 2002.

71. Rohini Shinde B.*, Vaibhav Jagtap A., Umesh Joshi P., R.B. Patil and R. D. Wagh on In Vitro Anthelmintic activity of Leucas cephalotes leaf extract, International Journal Of Drug Discovery And Herbal Res Earch (Ijddhr), 1(1): Jan-Mar: (2011), 25- 26.

72. Itoria Priyank And Jain Gaurav on to investigate leucas cephalotes for its antioxidant and hepatoprotective activity against ccl4 induced hepatotoxicity in swiss albino mice, International Journal Of Pharma And Bio Sciences, Vol 3/Issue 2/April June 2012

73. G. Sofi, ${ }^{*}$ Mohd. Yasir Khan, and M. A. Jafri on Hepatoprotective activity of Gumma (Leucas cephalotes Spreng.) against Carbon tetrachloride induced hepatotoxicity in wistar rats, Anc Sci Life. 2011 Oct-Dec; 31(2): 44-48.

74. Leucas cephalotes regulates carbohydrate and lipid metabolism and improves antioxidant status in IDDM and NIDDM rats, $\underline{\mathrm{J}}$ Ethnopharmacol. 2010 Jan 8;127(1):98-102. doi: 10.1016/j.jep.2009.09.042. Epub 2009 Sep 30.

75. Carbonic Anhydrase I and II Inhibition with Natural Products: Leucas cephalotes Pharmacognosy Communications www.phcogcommn.org, Volume1 Issue 2 | Oct-Dec 2011. 